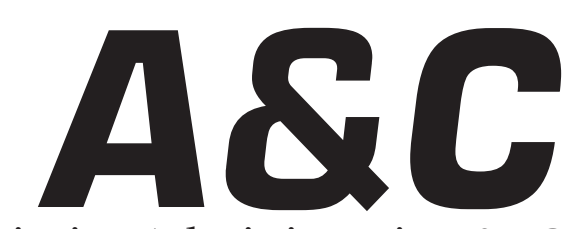

Revista de Direito Administrativo \& Constitucional

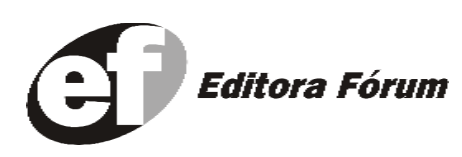

A\&C R. de Dir. Administrativo e Constitucional, Belo Horizonte, ano 4, n.17, p. 1-255, jul./set. 2004 


\section{A\&C REVISTA DE DIREITO ADMINISTRATIVO E CONSTITUCIONAL}

\section{IPDA}

Instituto Paranaense

de Direito Administrativo

Direção Geral

Romeu Felipe Bacellar Filho

Direção Editorial

Paulo Roberto Ferreira Motta

Direção Executiva

Emerson Gabardo

Conselho de Redação

Edgar Chiuratto Guimarães

Adriana da Costa Ricardo Schier

Célio Heitor Guimarães

Conselho Editorial

Adilson Abreu Dallari Luís Enrique Chase Plate

Alice Gonzáles Borges Lúcia Valle Figueiredo

Carlos Ari Sundfeld Manoel de Oliveira Franco Sobrinho (in memoriam)

Carlos Ayres Britto Marçal Justen Filho

Carlos Delpiazzo Marcelo Figueiredo

Cármen Lúcia Antunes Rocha Márcio Cammarosano

Celso Antônio Bandeira de Mello Maria Cristina Cesar de Oliveira

Clèmerson Merlin Clève Nelson Figueiredo

Clóvis Beznos Odilon Borges Junior

Enrique Silva Cimma Pascual Caiella

Eros Roberto Grau Paulo Eduardo Garrido Modesto

Fabrício Motta Paulo Henrique Blasi

Guilhermo Andrés Muñoz (in memoriam) Paulo Neves de Carvalho (in memoriam)

Jaime Rodríguez-Arana Muñoz Paulo Ricardo Schier

Jorge Luís Salomoni Pedro Paulo de Almeida Dutra

José Carlos Abraão Regina Maria Macedo Nery Ferrari

José Eduardo Martins Cardoso Rogério Gesta Leal

José Luís Said Rolando Pantoja Bauzá

José Mario Serrate Paz Sérgio Ferraz

Juan Pablo Cajarville Peruffo Valmir Pontes Filho

Juarez Freitas Yara Stropa

Julio Rodolfo Comadira Weida Zancaner

Os conceitos emitidos em trabalhos assinados são de responsabilidade de seus autores, que gozam de inteira liberdade de opinião.e-mail para remessa de artigos, pareceres e contribuições: e.gab.@uol.com.br

ou conselho@editoraforum.com.br Endereço para envio de contribuições: Editora Fórum

Revista A\&C, Av. Afonso Pena, 2770, 15\%16ª andar, Funcionários, CEP 30130-007 - Belo Horizonte - MG

A\&C Revista de Direito Administrativo e Constitucional. Ano 3, n. 11, jan./mar. 2003. Belo Horizonte: Fórum, 2003.

Trimestral

ano 1, n.1, 1999 até ano 2, n.10, 2002 publicada pela Editora Juruá em Curitiba

ISSN: $1516-3210$

1. Direito Administrativo. 2. Direito Constitucional. I. Fórum.

CDD: 342 CDU: 33.342
Editor responsável: Luis Cláudio Rodrigues Ferreira Projeto gráfico: Luis Alberto Pimenta

Diagramação: Luis Alberto Pimenta

Revisora: Olga M. A Sousa

Pesquisa jurídica: Fátima Ribeiro - OAB/MG 74868 Bibliotecária: Nilcéia Lage de Medeiros -

CRB 1545/MG - $6^{\mathrm{a}}$ região

(C) Editora Fórum Ltda 2004.

Proibida a reprodução total ou parcial desta obra,

por qualquer meio eletrônico, inclusive por processos xerográficos, sem autorização expressa do editor.

Distribuída em todo o território nacional

Assinaturas e comercialização:

Editora Fórum, Av. Afonso Pena, 2770, 15-16 andar, Funcionários, CEP 30130-007 - Belo Horizonte - MG Tel.: (31) 2121-4900 - 0800 704-3737

e-mail: editoraforum@editoraforum.com.br site: www.editoraforum.com.br 


\title{
Final de Mandato dos Atuais Prefeitos à Luz da Lei de Responsabilidade Fiscal
}

\author{
Reinaldo Moreira Bruno \\ Advogado. Mestre em Direito. Professor da Cadeira de Direito Administrativo da Unimes e da \\ Unimonte - Santos
}

\begin{abstract}
Sumário: 1 Introdução - 2 Uso da renúncia fiscal - 3 Gastos com pessoal 3.a Quanto à revisão geral dos vencimentos dos servidores - 3.b Quanto à eventual sobra de recursos do FUNDEF - 3.c Necessidade de aumento das despesas na área da saúde no período, até o exercício de 2004 - 4 Elevação do nível de endividamento - 5 Restos a Pagar e o artigo 42 da Lei Responsabilidade Fiscal - 6 Despesas assumidas nos últimos dois quadrimestres de mandato de prefeitos sem infringir o artigo 42 da Lei de Responsabilidade Fiscal - Bibliografia
\end{abstract}

\section{Introdução}

O final de mandato de cada Chefe de Poder constituiu-se, durante muitos anos, em um dos momentos mais agudos da vida dos Municípios brasileiros principalmente após a possibilidade da reeleição dos prefeitos, por expresso permissivo constitucional.

Sem a existência de tal instituto entre nós, já era muito comum os mandatários assumirem compromissos e práticas abusivas de endividamento, tudo em nome da manutenção do poder pelo grupo a que integravam.

Operações de Crédito por Antecipação de Receita, concessão de reajuste geral a servidores acima dos limites possíveis, elevação dos níveis de endividamento sem preocupação com a transferência para o sucessor, desapropriações para realização de obras sem o pagamento da justa e prévia indenização ao expropriado, concessão de isenções tributárias indiscriminadamente, além da realização de despesas que não podiam ser integralmente cumpridas naquele mesmo exercício que, se da mesma corrente política, suportaria sem reclamar, eis que beneficiário de tais ações, eram práticas muito comuns de serem verificadas, entre outras, durante o período pré-eleitoral.

Ciente destes desmandos na Administração dos Municípios, tanto os técnicos do BNDES como o próprio Congresso laboraram no sentido de impedir as práticas mais comuns em final de mandato, evitando elevar o nível de endividamento, como também desestimulando a corrida a Brasília à procura de financiamentos para dívidas encontradas. 


\section{Uso da renúncia fiscal}

Muito comum a utilização da renúncia de receitas em finais de mandatos, concedendo anistias, remissões, isenções a aposentados e outras formas de abrir mão de recursos, tudo em nome de ações eminentemente populistas, sem qualquer planejamento ou responsabilidade, visando apenas a obtenção de votos para a permanência no poder. Tal prática acaba por ser coibida em diversos dispositivos da Lei de Responsabilidade Fiscal, mais precisamente pelos artigos $5^{\circ}$, II, artigo 11, parágrafo único e 14 da Lei Complementar 101 de 04 de maio de 2000.

Ao tratarmos das vedações em relação a renúncia fiscal no tocante a ações vedadas, já afirmamos:

O texto legal, de caráter evidentemente restritivo a ação do administrador ou, da ação governamental como ensina Hely, não abrange reduções genéricas de alíquotas, de base de cálculo, tampouco benefícios e incentivos relativos a receitas de natureza não tributária, como os preços públicos por exemplo.

A Lei de Responsabilidade Fiscal neste dispositivo, limita tão somente aqueles benefícios discriminatórios, autorizando a redução de alíquotas, por exemplo, do IPTU, do ISS ou outro tributo de competência municipal em caráter absolutamente genérico, abrangendo a todos sem caráter de discriminação.

Cabe aqui esclarecer-se que, isenção ou redução em caráter não geral do benefício é aquele que deve ser concedida, mediante preenchimento das condições e requisitos estabelecidas na lei que o concede e, acaba por efetivar-se por ato de autoridade pública competente para tal. ${ }^{1}$

\section{E concluíamos:}

Verifica-se que, medidas que tenham caráter de renunciar a receita tributária exigem do administrador uma planificação, onde deixa de agir por mero instinto ou, ações meramente politiqueiras, que acabam lançando seus Municípios em autênticas aventuras, que acabam por sufocar e comprometer futuras administrações, tudo em nome de um projeto político pessoal ou partidário. ${ }^{2}$

\section{Gastos com pessoal}

A utilização da máquina administrativa também constitui-se em prática usual nos Municípios em períodos de mudança no comando destes, a partir da concessão de aumentos dos vencimentos, concessão de gratificações, adicionais casuísticos e outras formas de oferta de vantagens a servidores que, ante a concentração e organização, acabam por constituir-se em importantes BRUNO, Reinaldo Moreira. Lei de Responsabilidade Fiscal \& Orçamento Publico Municipal. Curitiba: Juruá, 2003, p. 131-132.

2 Op. cit., p. 133

A \& C R. de Dir. Administrativo e Constitucional, Belo Horizonte, ano 4, n. 17, p. 139-170, jul./set. 2004 
e decisivos cabos eleitorais.

Não obstante o tratamento no Capítulo IV, Seção II da Lei de Responsabilidade Fiscal, onde limites rigorosos são impostos, com aferição periódica, os técnicos que elaboraram a proposta aprovada no Congresso fizeram inserir no artigo 21, regra proibitiva de aumento de despesa com pessoal neste período:

Artigo 21 - É nulo de pleno direito o ato que provoque aumento da despesa com pessoa e não atenda:

(...)

Parágrafo Único - Também é nulo de pleno direito o ato que resulte aumento da despesa com pessoal expedido nos cento e oitenta dias anteriores ao final do mandato do titular do respectivo Poder ou órgão referido no artigo 20.

Ante tal dispositivo, cabe observar algumas das situações corriqueiras do cotidiano da Administração dos Municípios que os Prefeitos e seus auxiliares acabam por enfrentar, no que tange a despesas com pessoal e que ocorrem nos últimos cento e oitenta dias de mandato. Importante, ainda, ressaltar que estas situações além do momento de ocorrência no período vedado, ainda promovem aumento de despesas.

Servidor público e sua remuneração é um tema que ocasiona permanentemente questões muito interessantes e acaba tornando extremamente complexa a atuação do gestor das finanças públicas.

As nuances no cotidiano são várias, em uma área em que há mandamentos constitucionais, com toda uma legislação produzida pelo ente, anterior ou mesmo posterior à edição da Lei de Responsabilidade Fiscal e que poderão ser invocados pelo interessado junto a Administração.

Como resolver aparentes conflitos entre direitos regularmente constituídos dos servidores e a vedação da elevação das despesas com pessoal nos termos do artigo 21 e seu parágrafo único da Lei de Responsabilidade Fiscal?

O Tribunal de Contas do Rio Grande do Sul, atendendo a consulta formulada, além de manifestar-se conclusivamente quanto a diversas situações enfrentadas pela Administração Pública nos últimos cento e oitenta dias de mandato dos Prefeitos, em caráter meramente exemplificativo e não exaustivo, elenca uma série de situações, como se observa no resumo a seguir:

Lei de Responsabilidade Fiscal. Despesas com pessoal nos 180 dias anteriores 
ao final do mandato. Textos legais exigem interpretação sistemática, sob pena de deturpação dos fins por eles pretendidos. A Lei de Responsabilidade Fiscal visa a coibir a prática, pelo administrador, de atos atentatórios ao interesse público mas, jamais, a paralisação da administração. A regra geral de proibição de aumento de despesas com pessoal no período circunscrito pelo parágrafo único do art. 21 da LRF não veda a mera prática de atos administrativos vinculados, que apenas concretizam comandos legais, caracterizando poder-dever do administrador de realizar os fins essenciais da administração pública.

"Assim, e com caráter exemplificativo, e considerando ainda as hipóteses específicas elencadas nas fls. 2 e 3 do Processo no 5010-02.00/01-6, enumeram-se as seguintes despesas com pessoal que podem ser assumidas pelo titular de órgão ou Poder, nos 180 dias anteriores" ao término do seu mandato, consoante "vedação posta no parágrafo único do art. 21 da LRF, mesmo que impliquem em aumento desta despesa, como segue":

“1) Provimento de cargos efetivos vagos, preexistentes, quer em substituição de servidores inativos, falecidos, exonerados, ou seja qual for a causa da vacância;

“2) Provimento de cargos efetivos vagos, seja qual for a causa da vacância, inclusive por vagas que venham a ser concretizadas no período de vedação, desde que a respectiva autorização legislativa para sua criação tenha sido encaminhada, pelo titular de Poder ou órgão competente, ao Poder Legislativo, antes do início daquele prazo e, isto, porque a demora, aqui, cabe ao Legislativo, não se podendo, por isso, imputar ao administrador ilegitimidade para a prática de tais atos;

“3) Nomeação para cargos em comissão pré-existentes que vagarem, no período;

“4) Nomeação para cargos em comissão cujas vagas venham a ser concretizadas no período de vedação, desde que a iniciativa legislativa para sua criação tenha sido exercida pelo respectivo titular de Poder ou órgão e encaminhada ao Poder Legislativo antes do início daquele prazo, pelas razões expostas no $\mathrm{n}^{\mathrm{o}} 2$, supra;

“5) Contratação temporária de pessoal, porque autorizada pela própria Constituição Federal, no inciso IX do art. 37, sempre que necessário para 'atender a necessidade temporária de excepcional interesse público’, devendo estar caracterizada a emergência legitimadora desta forma de contratação;

“6) Designação de funções gratificadas e suas substituições, bem como atribuição de gratificações de representação, criadas por legislação anterior ao período de vedação;

“7) Designação de funções gratificadas ou suas substituições, bem como atribuição de gratificações de representação, quando sua instituição for concretizada posteriormente, desde que o respectivo projeto de lei para sua criação tenha sido encaminhado pelo Poder ou órgão, a quem cabe sua iniciativa legislativa, ao Poder Legislativo, antes do início do prazo excepcionado pela LRF;

“8) Realização de concurso público, até porque esta é a forma constitucional regular de provimento de cargos públicos (inciso II, art. 37 da Constituição Federal);

“9) Concessão de vantagens, inclusive as temporais — ex facto temporis — reguladas 
em lei editada anteriormente ao período de vedação, porque estes são benefícios pessoais do servidor, já adquiridos;

“10) Concessão de promoções, reguladas em lei editada anteriormente ao período de vedação, que deverão ser concedidas nos termos, na forma e segundo os requisitos específicos previstos na respectiva legislação reguladora preexistente ao período de vedação. A efetivação de promoções, em muitas situações, é, inclusive, indispensável à continuidade dos serviços públicos como, por exemplo, para fins de provimento de comarcas ou regionais de órgão, caso do Poder Judiciário, Ministério Público, do próprio Tribunal de Contas, e outros;

“11) Honorários, seja em função da participação do servidor como membro de banca de concurso, ou de sua gerência, planejamento, execução ou outra atividade auxiliar a ele correlata, em razão de que esta é remuneração a ele devida por exercício de atividade extra cargo indispensável à prestação dos serviços públicos e/ou sua continuidade. Aliás, não teria sentido aceitar gastos com realização de concurso público se não se admitir o pagamento de honorários aos membros da banca, bem como pelo exercício de outras funções correlatas ao concurso, pois esta negativa estaria inviabilizando a realização do certame;

“12) Pagamento de honorários a servidor por treinamento de pessoal (inciso IV, art. 85, e inciso III, art. 121 do Estatuto do Servidor Público do RS), não se inclui na vedação do parágrafo único do art. 21 da LRF, na medida em que estas atividades são necessárias ao aprimoramento do quadro de servidores e, pois, à otimização dos serviços públicos prestados ou disponibilizados. A única exigência para pagamento destes honorários no período referido será sua devida motivação, que deverá deixar clara a indispensabilidade da realização destas despesas no período excepcionado;

“13) Pagamento de honorários a servidor por atuação como professor em cursos legalmente instituídos (inciso IV do art. 85 e inciso IV do art. 121 do Estatuto do Servidor Público do RS), pelas mesmas razões constantes do item anterior e nas mesmas condições nele elencadas;

“14) Concessão de revisão salarial geral anual aos servidores públicos, prevista no inciso X do art. 37 da Constituição Federal, desde que existente política salarial prévia;

“15) Não é admissível, contudo, a concessão de reajustes salariais setorizados por categorias, instituído no período de vedação;

“16) Concessão de aumentos salariais previstos em norma legal editada anteriormente ao período de vedação, com repercussão, nele, de parcelas determinadas na respectiva lei reguladora”. FONTE: Parecer no 51/2001 - Processos NoS 5.010-02.00/01-6 e 4.971-02.00/01-6.

Dentre estas situações observe-se aquelas referentes a adicionais por tempo de serviço e promoções funcionais, extremamente comuns nos Estatutos de Servidores Municipais do país, cuja concessão dá-se a partir do transcurso do lapso temporal pré-estabelecido e preenchidos os requisitos legais. Preenchidas as condições estabelecidas em lei, o servidor passa a ter direito a vantagem, e torna a matéria absolutamente vinculada ao A \& C R. de Dir. Administrativo e Constitucional, Belo Horizonte, ano 4, n. 17, p. 139-170, jul./set. 2004 
Administrador, ou seja, terá necessariamente que ser deferida ao servidor.

A Corte Paranaense de Contas em atendimento a consulta formulada, manifestou-se na mesma linha do Tribunal de Contas do Rio Grande do Sul, supra-reproduzida a decisão nos itens 9 e 10 acima, assim estabelecendo:

\section{ATOS INVOLUNTÁRIOS E AUTOMÁTICOS.}

Ementa

Consulta. Promoções e adicionais previstos de implantação automática na legislação municipal, efetuadas nos 180 dias finais do mandato do Prefeito, que resultem em aumento de despesa, podem ser efetuadas, por revestirem-se de legalidade e não afrontarem dispositivos legais pertinentes à matéria.(g.m.) Protocolo: 263237/00-TC. - Sessão: 25.01.01 - Decisão: Resolução 415/01-TC - Relator: Conselheiro Nestor Baptista

Há, porém, outras situações a serem observadas além destas indicadas, que impõem verificação no sentido de estabelecer-se um mínimo de segurança ao gestor dos recursos municipais neste período tão delicado da vida dos Municípios.

Outras situações merecem tratamento, eis que oriundas de expressos mandamentos constitucionais, ainda, aquelas que materialmente obrigam o administrador como pode observar-se a seguir:

a) a revisão geral anual dos servidores, inscrita no artigo 37, $\mathrm{X}$, com redação alterada pela Emenda Constitucional n ${ }^{\circ}$ 19/98;

b) a questão dos recursos do FUNDEF, vinculados em percentual equivalente a $60 \%$ de seu total para pagamento de professores, a partir do que dispõe o artigo $60, \S 5^{\circ}$, do Ato das Disposições Constitucionais Transitórias, com redação formulada pela Emenda Constitucional $n^{\circ} 14 / 96$;

c) a necessidade premente de aumento das despesas na área da saúde no período, até o exercício de 2004;

d) contratações para atender excepcional interesse público na Educação.

Nas três primeiras situações verifica-se expressa determinação constitucional no sentido da prática de atos que impõem o aumento de dispêndio de recursos com pessoal.

Seria então tal dispositivo da lei fiscal inconstitucional sob este

A \& C R. de Dir. Administrativo e Constitucional, Belo Horizonte, ano 4, n. 17, p. 139-170, jul./set. 2004 
aspecto de, frontalmente, vedar o cumprimento da Carta em anos em que se encerra o mandato de Prefeitos, Governadores ou Presidente da República?

Na verdade, esta questão não requer como solução afastar o texto legislativo fiscal do mundo jurídico por vício de inconstitucionalidade.

Impõe ao operador do direito ao analisar o dispositivo, artigo 21 e seu parágrafo único da Lei de Responsabilidade Fiscal, promover a interpretação compatibilizando-a com o texto constitucional, sendo que tal tarefa é perfeitamente possível.

\section{3.a Quanto à revisão geral dos vencimentos dos servidores}

A Lei de Responsabilidade Fiscal não veda o reajuste anual dos servidores estabelecido na Constituição, simplesmente limita o período em que venha a ser realizada.

Mesmo assim, se já houver sido editada lei municipal previamente estabelecendo a política remuneratória dos servidores, inclusive prevendo a data da revisão anual, e a edição de lei que estabeleça o percentual de reajuste em período anterior ao vedado, forçoso concluir que ao Administrador cabe apenas e tão-somente cumprir o mandamento expresso e determinar os pagamentos.

Nesta linha decidiu o Tribunal de Contas do Estado do Rio Grande do Sul, como se observa a seguir:

DECISÃO: O Tribunal Pleno, em Sessão de 07-3-2001, ressalvando o teor do artigo 138, parágrafo $2^{\circ}$, do Regimento Interno deste Tribunal, no sentido de que a resposta à Consulta não constitui prejulgamento de fato ou caso concreto, acolhe o Voto do Senhor Conselheiro-Relator, e, à unanimidade, decide encaminhar ao ilustre Consulente, cópia da Informação no 126/2000 da Consultoria Técnica e do Parecer $n^{\circ}$ 05/2001 exarado pela Doutora Rosane Heineck Schmitt, acolhidos nesta data, uma vez que tais peças oferecem ao Interessado, em tese e a título de colaboração, importantes subsídios de caráter pedagógico acerca da matéria questionada.

"EM CONCLUSÃO, e em resposta ao indagado, pode o Município consulente conceder a referida revisão geral anual de remuneração de seus servidores, nos termos do inciso $\mathrm{X}$ do art. 37 da Constituição Federal, desde que para tanto esteja autorizado por legislação municipal prévia, reguladora da matéria e editada anteriormente aos cento e oitenta dias do final de mandato do titular do Poder Executivo, desde que observados, ainda, os demais requisitos constitucionais, legais e especialmente os postos na Lei Complementar no 101/2000 (dotação orçamentária, limites de despesa de pessoal, etc.), antes referidos." (2) (g.m.) (1) INFORMAÇÃO No 126/2000 e (2) Parecer no 5/2001 - Processo $\mathrm{N}^{\circ}$ 6.776-02.00/00-0.

A \& C R. de Dir. Administrativo e Constitucional, Belo Horizonte, ano 4, n. 17, p. 139-170, jul./set. 2004 


\section{3.b Quanto à eventual sobra de recursos do FUNDEF}

Aos recursos oriundos do Fundo de Manutenção e Desenvolvimento do Ensino Fundamental e Valorização do Magistério, conhecido com FUNDEF, instituído por mandamento constitucional, há expressa reserva de não menos que sessenta por cento de seus recursos com a remuneração de professores.

Tais recursos são repassados periodicamente aos Municípios e devem ser efetivamente empregados naquele exercício, não podendo aqueles ser dada outra destinação que não o pagamento de professores com efetiva atuação em sala de aula.

Imagine-se no último exercício do mandato do Prefeito, já tendo ingressado no período vedado pela Lei de Responsabilidade Fiscal, constata o Prefeito, a existência de recursos relativos ao percentual reservado ao pagamento dos professores. É possível, com este saldo, vir a ser concedido abono aos professores do Ensino Fundamental que estejam efetivamente em sala de aula?

Em respeito à soberania do texto constitucional que embasa todo o ordenamento jurídico nacional, a disposição da lei fiscal não tem incidência nesta situação, eis que se trata de recursos oriundos de Fundo, com percentual expressamente vinculado a pagamento de pessoal, no caso Magistério de Ensino Fundamental em sala de aula, ratificada esta posição, a partir do princípio da hierarquia das leis onde, não cabe a dispositivo infraconstitucional dispor de forma diferente o que dispõe a Carta Magna.

Neste sentido, é de observar-se a decisão do Tribunal de Contas Gaúcho, que assim manifestou-se quanto a esta questão:

DECISÃO: Tribunal Pleno em Sessão de 01.11.2000, ressalvando o teor do artigo 138, parágrafo $2^{\circ}$, do Regimento Interno deste Tribunal, no sentido de que a resposta à Consulta não constitui prejulgamento de fato ou de caso concreto, acolhe o Voto da Senhora Conselheira-Relatora e, à unanimidade, decide encaminhar à Autoridade consulente cópia da Informação n ${ }^{\circ}$ 89/2000, da Consultoria Técnica e do Parecer $n^{\circ}$ 63/2000, da lavra do Auditor Substituto de Conselheiro Vergilio Perius, acolhidos nesta data, por bem representarem o pensamento desta Corte acerca da matéria versada nos presentes autos.

"1 - É possível, sob forma de abono, conceder aos professores o pagamento do saldo dos $60 \%$ do FUNDEF, previstos no art. 60 , $\$ 5^{\circ}$ do A.D.C.T.

"2 - Sem ser definitivo, entende-se pelo princípio da hierarquia das leis, a vedação do art. 21, parágrafo único da Lei Complementar $n^{\circ}$ 101/2000 não se aplica ao caso. De qualquer modo fica recomendada orientação junto à Justiça Eleitoral nos termos do Parecer n ${ }^{\circ}$ 126/94, aprovado na sessão de 05-10-94, pelo Tribunal Pleno." (2) (1) INFORMAÇÃ̃ No 089/2000 e (2) PARECER No

A \& C R. de Dir. Administrativo e Constitucional, Belo Horizonte, ano 4, n. 17, p. 139-170, jul./set. 2004 
63/2000 - PROGESSO No 5.993-02.00/00-4

\section{3.c Necessidade de aumento das despesas na área da saúde no período, até o exercício de 2004}

Esta situação que pode deparar-se normalmente o Administrador do Município tem aspectos normativos interessantes, eis que, a partir do que dispõe o artigo 21, parágrafo único da Lei de Responsabilidade Fiscal, são nulos todos os atos que aumentem a despesa com pessoal nos últimos 180 dias de mandato dos Prefeitos, em nosso caso.

A partir da edição da Emenda Constitucional no 29/2000, inseriu-se no Ato das Disposições Constitucionais Transitórias o artigo 77, estabelecendo percentuais mínimos de dispêndios com serviço público de saúde para os três níveis de poder da Federação.

Aos Municípios, o referido artigo 77 do ADCT em seu inciso III, reservou $15 \%$ do produto das receitas de impostos; a repartição de tributos da União e dos Estados nos termos do artigo 158 da CF e a participação no Fundo de Participação dos Municípios, nos termos do artigo 159, I, b e $\S 3^{\circ}$ também da Constituição Federal.

Poderão os Prefeitos deparar-se com a seguinte situação: nos dois quadrimestres de seu último ano de mandato, que há a necessidade de pessoal para aperfeiçoamento dos serviços e que não atingiram o limite constitucional mínimo de despesas com saúde.

Estaria vedada a ampliação do quadro de pessoal nesta importante área de serviço público a partir do que dispõe o artigo 21, §único da Lei de Responsabilidade Fiscal?

A resposta a esta indagação é negativa.

Dispõe a Carta Magna determinado índice percentual mínimo de despesas com saúde, ainda não atingido pelo ente, no caso o Município, e ainda no campo fático, há a necessidade do atendimento às necessidades do cidadão.

Ante a incidência de alguns princípios na situação colocada, estará o Município autorizado a promover tais contratações a partir, inicialmente, do princípio da hierarquia das leis, ou seja, o mandamento constitucional deve ter prevalência sobre o dispositivo complementar. Incidem, ainda, pelo menos três princípios que devem nortear as ações administrativas: indisponibilidade do interesse público, da continuidade da prestação do serviço público e ainda, o da motivação.

Analisando consulta quanto a esta possível situação, o Tribunal de

A \& C R. de Dir. Administrativo e Constitucional, Belo Horizonte, ano 4, n. 17, p. 139-170, jul./set. 2004 
Contas do Rio Grande do Sul assim posicionou-se:

DESPESAS COM PESSOAL. VEDAÇÕES EM FINAL DE MANDATO. SAÚDE. AUMENTO DE DESPESAS COM PESSOAL

"Além disso, na hipótese de haver a extrema necessidade de aumento das despesas com pessoal, na área da saúde, em decorrência do atingimento dos limites mínimos em questão, em especial para o exercício de 2000, não é demais alertarmos para a vedação posta no parágrafo único do art. 21 da Lei Complementar $n^{\circ}$ 101/2000, também conhecida como Lei de Responsabilidade Fiscal - LRF, como segue:

“ 'Art. 21. É nulo de pleno direito o ato que provoque aumento da despesa com pessoal e não atenda:

“ 'I - as exigências dos arts. 16 e 17 desta Lei Complementar, e o disposto no inciso XIII do art. 37 e no §1o do art. 169 da Constituição;

“ 'II - o limite legal de comprometimento aplicado às despesas com pessoal inativo.

“ 'Parágrafo único. Também é nulo de pleno direito o ato de que resulte aumento da despesa com pessoal expedido nos cento e oitenta dias anteriores ao final do mandato do titular do respectivo Poder ou órgão referido no art. 20.'

“(..)

Na linha de entendimento firmada no Estudo Sobre Alguns Dispositivos da Lei de Responsabilidade Fiscal, consubstanciado no Processo ${ }^{\circ}$ 6.760-02.00/00-1, aprovado em Sessão Plenária de 08-11-2000, quanto a tal dispositivo da LRF, "na ocorrência da citada hipótese - extrema necessidade de aumento das despesas com pessoal, na área da saúde, em decorrência do atingimento dos limites mínimos em questão, em especial para o exercício de $2000-$, o comando constitucional" posto no artigo 77 do ADCT da Lei Maior, "a nosso ver, teria prevalência sobre a norma posta na LRF, face ao princípio da hierarquia das leis." $O$ citado art. 77 estabelece que, "até o exercício financeiro de 2004, os recursos mínimos aplicados nas ações e serviços públicos de saúde serão equivalentes" àqueles elencados em seus incisos I a III. (g.m.) FONTE: INFORMAÇÃO No 102/2000 - PROCESSO No 9.099-02.00/00-6.

Cabe ressaltar que esta regra dispondo sobre percentual mínimo de dispêndio de recursos com a saúde estabelecida pela Emenda Constitucional $\mathrm{n}^{\mathrm{o}} 29 / 00$, poderá ter vigência maior que a pré-estabelecida, relativa ao exercício de 2004.

Nos termos do artigo 77, §4 do ADCT, na hipótese de omissão do legislador complementar em estabelecer outro índice de dispêndio mínimo de recursos com a saúde para 2005 e exercícios subseqüentes, permanecerá tratando a matéria este mesmo dispositivo constitucional, ou seja, permanecerá o assunto tendo tratamento constitucional e a solução para problemas análogos a partir de 2005 poderá continuar sendo a mesma. 
Não obstante tais situações não encontrarem vedação no período estabelecido no artigo 21 da Lei de Responsabilidade Fiscal, não se encontra dispensado o Administrador, no caso o Prefeito e seus auxiliares, de adotar as demais cautelas e disposições da Lei de Responsabilidade Fiscal.

Em ambas as situações, a prática de atos que importem aumento de despesas com pessoal no período previsto no parágrafo único do art. 21 da Lei Complementar $n^{\circ} 101 / 00$, fica condicionada, também, ao atendimento do contido no caput e no $\S 1^{\circ}$ do art. 169 da Constituição Federal, bem como aos limites de despesas com pessoal previstos no art. 20 e, ainda, ao disposto em seus artigos 15, 16, 17 e 42, todos da Lei de Responsabilidade Fiscal.

Torna-se importante observar não apenas nestas situações aqui tratadas e elencadas, como também na prática dos demais atos realizados pela Administração Pública.

Neste sentido, torna-se necessário observar a hipótese de nomeação de servidores, no período indicado no artigo 21 da Lei de Responsabilidade Fiscal, para ocupar cargo público após aprovação em regular concurso público.

No primeiro momento, observando-se o expresso mandamento legal, poder-se-ia concluir que tais atos seriam considerados nulos de pleno direito e, portanto, absolutamente vedados no período indicado. Este foi o entendimento do Tribunal de Contas do Estado do Paraná, ao negar registro ao ato admissional de Oficial de Justiça, por considerá-lo nulo de pleno direito, eis que ocorrido no período estabelecido no artigo 21 da Lei de Responsabilidade Fiscal e portanto, nulificador do ato.

Em mandado de segurança impetrado pelo interessado o Tribunal de Justiça do Estado do Paraná, manifestou-se no sentido de que a interpretação da norma legal deve ser feita a partir de todo o ordenamento jurídico e não apenas da norma positivada. A decisão foi assim ementada: MANDADO DE SEGURANÇA - 134.747-5, de Curitiba

Mandado de Segurança. Oficial de Justiça. Ato de Nomeação Registro. Negativa do Tribunal de Contas. Decreto Judiciário no 292, de 13 de novembro de 2000. Vedação decorrente do disposto no artigo 21, da Lei Complementar no 101/2000. Verificação Acerca da Abrangência do Dispositivo de Lei. Ausência de Contrariedade no Caso Específico, à Previsão de Vacância do Cargo que Ocorreu em Gestão Anterior Àquela em que Achou Provido o Cargo Vago pelo Impetrante. Ausência de Incremento de Despesas com Pessoal. Ofensa a Direito Líquido e Certo Materializado. Segurança Concedida, Confirmando-se Liminar Ante- 
riormente Deferida.

A ementa do julgado já sinaliza a construção do raciocínio desenvolvido, que fica mais evidente ao verificar-se a motivação do voto do Desembargador Relator, Nério Spessato Ferreira, em 15 de agosto de 2003:

Descoberta a ratio legis e os princípios que informam o dispositivo e fixada a necessidade do exame e ponderação dos princípios fundamentais, dos gerais e dos setoriais, a determinação dos atos efetivamente vedados pelo artigo 21 , parágrafo único, da Lei de Responsabilidade Fiscal torna-se um pouco mais fácil, bastando o emprego da seguinte premissa: desde que o ato não viole os princípios que orientam a Lei Complementar $n^{\circ} 101 / 00$, ou seja, desde que ele corresponda ao conteúdo dos princípios da moralidade administrativa etc., mesmo importando aumento de despesa e seja praticado dentro do período suspeito, ele será perfeitamente legal, desde que atendidos outros dispositivos da referida lei, como a existência de previsão orçamentária, a obediência ao limite de despesas etc.

Com isso, princípios importantes como o da continuidade do serviço público, da legalidade e da eficiência são garantidos, não contrariando o princípio da moralidade, por exemplo, o comportamento do Administrador que, não obstante o aumento de despesas com pessoal, cumpre a lei ou decisóes judiciais (o seu ato não será contrário a princípios éticos na medida em que outros princípios o justificam).(g.m.)

Os atos que implicam aumento de despesa com pessoal, quando praticados, recebem grande atenção e divulgação, eis que realizados em meio ao árduo processo de campanha eleitoral onde adversários digladiamse e muitas ações administrativas acabam sendo levadas à apreciação de representantes do Ministério Público e do Judiciário.

Ressalte-se que nos termos do artigo 359-G do Código Penal constituise crime: "Ordenar, autorizar ou executar ato que acarrete aumento de despesa total com pessoal, nos cento e oitenta dias anteriores ao final de mandato ou da legislatura."

Trata-se da observância do princípio da motivação, importante instrumento de verificação da legitimidade das ações administrativas.

Em decisão monocrática o Conselheiro Eduardo Bittencourt de Carvalho, do Tribunal de Contas do Estado de São Paulo, em uma manifestação com caráter didático acaba por realçar esta necessidade de motivação, alertando para a análise conjuntural da nomeação de pessoal nos últimos 180 dias de mandato: 
PROCESSO: TC-001484/006/01

INTERESSADO: PREFEITURA MUNICIPAL DE BATATAIS

ASSUNTO: Admissão de Pessoal

EXERCÍCIO: 2000

Consoante tenho sustentado, "A suposta infração ao artigo 21, parágrafo único, da lei Complementar $n^{\circ} 101 / 00$, consoante assinalado pela auditoria, não merece prosperar, assistindo, pois, razão à municipalidade.

O dispositivo legal em tela, de fato, considera nulo de pleno direito o ato expedido nos 180 (cento e oitenta) dias anteriores ao final do mandato eletivo que provocar aumento de despesa com pessoal.

Parece-me, a propósito, que se trata de nulidade absoluta, portanto, não permite convalidação.

Sucede, porém, que não é a hipótese dos autos.

Com efeito, o simples fato de haver nomeação no período em que a Lei de Responsabilidade Fiscal considera nulo o ato que provocar aumento de despesa de pessoal, os $\mathbf{1 8 0}$ (cento e oitenta ) dias anteriores ao término do mandato, não se revela perfeito e acabado a ponto de constituir presunção de que tenha ocorrido majoração de gasto de pessoal, portanto, insuficiente para que se conclua que houve violação ao dispositivo legal em tela, originada pela nomeação de servidor.

Logo, não se pode afirmar que tal nomeação está irregular, vez que não se têm segurança e certeza de que ela ocasionou a majoração de gasto, mesmo por que, há diversas outras circunstâncias que devem ser sopesadas quando do exame da matéria, não podendo, pois, a análise restringir-se única e exclusivamente, conforme procedido pela fiscalização, ao interstício proibitivo estabelecido pelo diploma legal.

Assim, afigura-se-me bastante razoável que os gastos decorrentes de determinadas nomeaçóes havidas, dentro daquele período proibitivo, sejam compensados por fatos ocorridos que diminuam as despesas com pessoal, por exemplo, demissões e exonerações de servidores, término de contrato por prazo determinado, etc."

No caso concreto, contudo, consoante atestado pelo órgão técnico, não houve aumento de despesa de pessoal, daí por que não se falar em violação ao dispositivo legal mencionado. (g. m.) (DIÁRIO OFICIAL DO ESTADO DE SÃO PAULO No 197 - 16 DE OUTUBRO DE 2003)

É absolutamente imprescindível que a prática pelos gestores da coisa pública, de atos que venham a ensejar aumento com a despesa de pessoal, estejam acompanhados de ampla exposição dos motivos que justifiquem a prática do ato.

Tal observação torna-se imperiosa, a partir da necessidade de deixarse clara a legitimidade da ação administrativa, concomitantemente com sua 
prática, principalmente no que tange à demonstração das situações de fato que exijam a ação, ou mesmo a existência de prévio comando legal, anterior ao período vedado pela lei fiscal.

\section{Elevação do nível de endividamento}

Quanto ao nível de endividamento, onde há fixação de prazo de três quadrimestres para tornar ao patamar autorizado pela lei, com redução no primeiro de $25 \%$, ou seja, o legislador oferece ao Prefeito, em nosso caso, a possibilidade de retomar o patamar aceitável de endividamento em até um ano. Período bastante razoável considerando-se um mandato de quatro anos, com possibilidade de mais quatro ante o instituto da reeleição.

Mas, em último exercício de mandato, visando evitar despesas que tornem o Município inviável com um nível de endividamento inaceitável e transferindo ao sucessor um quadro absolutamente sombrio, a Lei de Responsabilidade Fiscal fez estabelecer restrições seríssimas para promover a recondução da dívida ao limite legal assim dispondo:

\section{Artigo 31}

Parágrafo Terceiro - As restrições do parágrafo primeiro aplicam-se imediatamente se o montante da dívida exceder o limite no primeiro quadrimestre do último ano de mandato do Chefe do Poder Executivo.

A realização de operações de crédito com base na antecipação de receita ao longo dos anos, constituiu-se na grande mola propulsora das eleições municipais, assegurando a manutenção de correntes políticas no poder, à custa de recursos oriundos destas operações de crédito, que eram realizadas sem grandes restrições, tendo apenas como partícipes instituição financeira e Município, tiveram um tratamento mais abrangente no item 4.7.

Este tratamento acabaria por tornar-se insuficiente ante a criatividade de nossos administradores e a "vontade" de ganhar eleições, tornaria praticamente insuficiente tais dispositivos limitadores.

Os técnicos e parlamentares responsáveis pela edição da Lei de Responsabilidade Fiscal, acabaram por tornar a vedação mais rígida, ao proibir a realização de tal operação de crédito no último ano de governo, como se observa a seguir:

Artigo 38

A \& C R. de Dir. Administrativo e Constitucional, Belo Horizonte, ano 4, n. 17, p. 139-170, jul./set. 2004 
(...)

IV- estará proibida:

$\mathrm{a}-\ldots \ldots . . . .$.

b- no último ano de mandato do Presidente, Governador ou Prefeito Municipal;

\section{Restos a Pagar e o artigo 42 da Lei Responsabilidade Fiscal}

As despesas de final de mandato também serviam como grande incentivador de campanhas eleitorais ao tornarem-se importantes aliados na atuação dos detentores do poder:

- ao oferecer a implantação de serviços sem previsão de recursos orçamentários;

- assistencialismo em larga escala;

- realização de obras e de serviços de manutenção de grande monta. Tais ações eram sempre realizadas a partir de um orçamento superdimensionado, onde o que importava era a existência de dotação orçamentária para realização do empenho. Já a fase de liquidação da despesa e seu efetivo pagamento estariam em novo mandato e o déficit orçamentário seria administrado pelo sucessor ou pelo reeleito.

Os Restos a Pagar decorrentes destes períodos tornavam insuportáveis os dois primeiros anos de governo que, na linguagem popular, era para pagar dívidas encontradas e dois anos para trabalhar e, ao final, contrair dívidas que seriam roladas ao sucessor, conforme encontravam os Prefeitos.

Feitas estas considerações imprescindíveis no que refere à despesa pública, o legislador infraconstitucional, ciente deste quadro, objetivando pôr fim a esta rotina de transferência de dívidas e de assegurar a manutenção do poder, a Lei de Responsabilidade Fiscal em seu artigo 42, assacou duro golpe a esta costumeira prática.

Estabeleceu que, no último ano de mandato nos dois últimos quadrimestres, o Prefeito Municipal só poderá assumir novos compromissos financeiros desde que sejam pagos até o final de seu mandato ou, se transferidos para o próximo exercício, existam recursos financeiros em caixa reservados para saldar tais compromissos.

Deixar o pagamento do décimo terceiro salário para o ano subseqüente, por exemplo, implica, necessariamente, na existência de recursos no cofre para ta l pagamento, ressaltando-se ainda que não poderão ser utilizados recursos oriundos da antecipação da receita de IPTU do exercício seguinte.

A partir de maio de 2000, início de vigência da Lei Complementar 
$\mathrm{n}^{\mathrm{o}} 101 / 00$, concomitantemente ao início do período eleitoral, instalou-se polêmica relativa ao que dispõe o artigo 42 da Lei de Responsabilidade Fiscal e sua eventual relação com os Restos a Pagar.

A discussão teve origem no estatuído no artigo 42 da Lei fiscal que assim dispõe:

Artigo 42- É vedado ao titular de Poder ou órgão referido no art. 20, nos últimos dois quadrimestres de seu mandato, contrair obrigação de despesa que não possa ser cumprida integralmente dentro dele, ou que tenha parcelas a serem pagas no exercício seguinte sem que haja suficiente disponibilidade de caixa para este efeito.

Parágrafo Único - Na determinação da disponibilidade de caixa serão considerados os encargos e despesas compromissadas a pagar até o final do exercício.

A partir desta disposição legal, notadamente após a edição da Lei $\mathrm{n}^{\mathrm{o}}$ 10.028/00, inseriu no Código Penal o artigo 359-f, que estabelece a pena de detenção de 06 meses a 02 anos, àquele que: "deixar de ordenar, de autorizar ou de promover o cancelamento do montante de Restos a Pagar inscrito em valor superior ao permitido em lei," gerou uma série de conclusões iniciais no seguinte sentido:

- Todas as dívidas devem ser pagas antes de entregar o cargo;

- Aquele que deixar dívidas para outro pagar, sujeita-se a cadeia;

- Não poderá haver inscrição em Restos a Pagar;

- Todos os empenhos teriam de ser cancelados.

Convém ressaltar que alguns autores já ao início da vigência da Lei de Responsabilidade Fiscal, em suas primeiras linhas quanto ao tema, já alertavam para cautelas a serem adotadas, como se observa em Flávio da Cruz e outros, já no ano de 2000, ocasião em que publicou seus comentários à novel lei, alertando àqueles apanhados em final de mandato com elevado nível de endividamento, e obrigados a atender o disposto no artigo 42 da lei fiscal:

Os entes da Federação e órgãos públicos que possuem grande endividamento serão forçados a, nesse período, reduzir ao máximo suas despesas correntes e ficarão, praticamente impedidos de realizar despesas de capital cujo valor não possa ser integralmente liquidado no exercício, tendo como alternativa tentar aumento da receita e outras medidas no mercado fornecedor, como, por exemplo, a licitação e contratação parcial de obras... ${ }^{3}$

Em outubro de 2000, mesmo mês de edição da Lei no 10.028/00, 
fez a Associação Paulista de Municípios circular, a título de orientação aos Municípios de São Paulo, parecer de seu corpo técnico que, sinteticamente, sugeria e:

- Cancelamento de empenhos e não de todos empenhos realizados no ano de 2000 sem, porém, cancelar crédito algum;

- Após a mudança de exercício, já na nova gestão, o empenho na dotação Despesa de Exercício Anterior, que deveria ser reforçada em termos de valores;

- Entendeu o subscritor do parecer mencionado que, a partir da Lei de Responsabilidade Fiscal só poderá ser inscrito em Restos a Pagar se houver disponibilidade financeira para liquidar;

- Teria a Lei de Responsabilidade Fiscal extinto a prática de inscrição em Restos a Pagar e no ano seguinte era pago como despesa extraorçamentária;

- Foi além tal orientação, após o cancelamento dos empenhos desde que não decorrentes de convênios, precatórios ou de cumprimento de mandamento constitucional, deveria ser reempenhado em ordem cronológica e pagos obedecida a ordem cronológica do artigo $5^{\circ}$ da Lei de Licitações, ou seja, a Lei $n^{\circ}$ 8.666/93 com suas alterações posteriores.

Com estas providências, o prolator do parecer entendia suficiente para afastar a incidência do disposto no artigo 359, "f" da Lei $\mathrm{n}^{\circ}$ 10.028/00.

Em posição contrária a esta defendida pela assessoria jurídica da entidade paulista de Municípios, encontramos as vozes de Amir Antonio Khair, Walter Penninck Caetano e Austen da Silva Oliveira, e representantes dos Tribunais de Contas Estaduais Flávio Correia de Toledo Junior, Simone Manassés Valaski, Carlos Maurício Cabral respectivamente de São Paulo, Paraná e Pernambuco, por ocasião de Simpósio realizado na cidade Paulista de Osasco, em 28 de junho de 2001.

Estas vozes, das mais abalizadas no cenário das finanças públicas, partem de pontos comuns para a construção do raciocínio, todos concluindo pela impossibilidade da realização de cancelamento de empenhos naquele momento, ou seja, ao final de 2000.

O mencionado artigo 42 da Lei Fiscal não trata de Restos a Pagar e sim apenas e tão-somente de vedar a assunção de obrigações nos últimos

${ }^{3}$ Lei de Responsabilidade Fiscal Comentada, p. 129.

A \& C R. de Dir. Administrativo e Constitucional, Belo Horizonte, ano 4, n. 17, p. 139-170, jul./set. 2004 
oito meses de mandato, sem disponibilidade financeira para tanto.

O simples cancelamento do empenho de despesa liquidada constitui-se em flagrante ilegalidade, eis que tal prática só pode ocorrer em relação a despesas que não foram efetivamente realizadas, portanto, não ensejando prejuízos a outrem.

Diferentemente, o empenho liquidado já foi atestado pelo ente com realização do objeto da contratação de forma absolutamente regular, com o reconhecimento formal desta condição, restando apenas o pagamento, ou seja, o negócio jurídico entre as partes operou-se regularmente, com uma das partes adimplindo integralmente o ajuste no que tange às obrigações que assumiu.

Convém ressaltar que, visando elidir toda e qualquer discricionariedade no momento de efetuar-se o pagamento, a Lei de Licitações em seu artigo $5^{\circ}$, estabeleceu a obrigatoriedade de observância da ordem cronológica de liquidação da despesa como norte para realização dos pagamentos pelo Poder Público, admitindo apenas que tal ordem poderia ser estabelecida a partir de cada fonte de custeio da mencionada despesa, ou seja, por unidades orçamentárias.

Admitida a orientação formulada pela Associação de Municípios Paulistas, o cancelamento implicaria no "desfazimento" total do negócio jurídico já concretizado em determinado dia, e no dia seguinte, como por encanto, refeito.

Este reparo à orientação formulada pela entidade de municípios de São Paulo, também veio a ser efetuado pelo Tribunal de Contas Estadual, ao ser provocado por consulta formulada pelo Prefeito Municipal de Palmeira d'Oeste, após sua posse em janeiro de 2001 e ter encontrado na contabilidade da Prefeitura a adoção daquela orientação, como se observa a seguir:

TRIBUNAL PLENO - SESSÃO DE 19.09.2001 - ITEM 23 CONSULTA TC016367/026/01

Consulente: Dirço Teruo Yamamoto - Prefeito do Município de Palmeira d'Oeste.

Assunto: Consulta sobre cancelamento de empenhos em exercícios anteriores. Os efeitos nefastos sobre o atual orçamento constituem efetiva preocupação a se ter em vista, como alertam ainda Flávio Toledo e Sérgio Rossi: "é preciso dizer aqui o óbvio, que tal manobra acarreta inúmeras dificuldades para o próximo gestor. A primeira delas é viabilizar recursos orçamentários e financeiros para honrar os contratos irregularmente anulados, nos quais, via de regra, já terá havido o adimplemento contratual por parte de terceiros (entrega de mercadorias

A \& C R. de Dir. Administrativo e Constitucional, Belo Horizonte, ano 4, n. 17, p. 139-170, jul./set. 2004 
e obras, prestação de serviços); "No entanto, dentro dos limites legais de ampliação das despesas e das metas de sua redução, creio devam os Srs. Prefeitos buscar o reempenhamento como rota corretiva dos atos praticados no exercício passado.É a proposta de orientação que faço em meu VOTO, sugerindo que seu conteúdo seja amplamente divulgado e disponibilizado aos atuais Prefeitos, pelos meios que Vossa Excelência, Senhor Presidente, entender mais adequados".

\section{RENATO MARTINS COSTA}

CONSELHEIRO

O quadro agrava-se ainda mais, pois, como proceder-se nesta situação em relação à ordem cronológica, se tais despesas seriam reempenhadas na dotação de Despesas de Exercícios Anteriores? Ressalte-se que esta dotação é única e não por unidade orçamentária ensejando assim, sempre algum tipo de prejuízo a fornecedor em relação a outrem.

Ademais, a orientação oferecida aos Municípios objetivava afastar a incidência da tipificação penal da conduta no que tange a inscrição em Restos a Pagar, obedecido o limite previsto em lei.

Qual o limite estabelecido em lei? Inexiste tal limite na legislação vigente.

O artigo 41 da Lei de Responsabilidade Fiscal estabelecia a nova definição de Restos a Pagar e em seu parágrafo segundo, impunha o limite para a inscrição nesta dotação, porém, tal dispositivo foi objeto de veto presidencial na íntegra do mencionado artigo, restando apenas o tratamento oferecido pela Lei $\mathrm{n}^{\mathrm{o}} 4.320 / 64$.

A seguir constata-se o tratamento de Restos a Pagar e inscrito no artigo 36 da Lei $n^{\circ}$ 4.320/64 que não estabelece limites, a partir do veto aposto pelo Presidente da República no artigo 41 da Lei Complementar $\mathrm{n}^{\mathrm{o}}$ 101/00, que assim dispõe:

Artigo 36- Consideram-se Restos a Pagar as Despesas empenhadas mas não pagas até o dia 31 de dezembro, distinguindo-se as processadas das não processadas.

Parágrafo Único - Os empenhos que correm à conta de crédito com vigência plurianual, que não tenham sido liquidados, só serão computados com Restos a Pagar no último ano de vigência do crédito.

Alguns mais afoitos procuraram justificar a existência de limite para inscrição em Restos a Pagar, a partir do disposto no artigo 55, III, b, 4 da Lei de Responsabilidade Fiscal.

Acolher-se esta argumentação ensejaria autêntica burla ao veto presidencial aposto ao 41 da lei fiscal, repristinando-o, situação não acolhida no Direito Brasileiro. 
Tal dispositivo legal encontra-se elencado na Seção da Lei Fiscal que estabelece a formalização do Relatório de Gestão Fiscal, não se constituindo, assim, em mandamento impositivo à Administração, e sim, tão- somente deverá ser observado quando da elaboração de um dos relatórios exigidos pela Lei de Responsabilidade Fiscal.

Na verdade, a grande questão enfrentada ao final do ano de 2000, que gerou enorme intranqüilidade tanto aos Prefeitos que deixavam o cargo como àqueles que estavam assumindo, é o entendimento que cada Tribunal de Contas da Federação oferecerá em suas manifestações e, por conseguinte, as conseqüências destas na esfera penal.

Esta intranqüilidade decorria de uma situação fática interessante, ou seja, os Prefeitos vinham trazendo em seus orçamentos, Restos a Pagar relativo a várias décadas, como afirmado por Celso Giglio, Prefeito de Osasco /SP, por ocasião da realização do simpósio referido.

Com a entrada em vigor da Lei de Responsabilidade Fiscal, já no período de imposição de restrições de gastos públicos nos dois últimos quadrimestres de mandato, a Administração deveria continuar suas tarefas do cotidiano, que demandam gastos públicos.

Como resolver o impasse relativo a dívidas anteriormente existentes e os gastos necessários para manutenção de serviços até o final do mandato, frente ao que dispõe o artigo 42 da Lei de Responsabilidade Fiscal e a questão penal incidente?

Nesta hipótese, estas despesas que foram efetivadas sem a necessária disponibilidade de recursos nos dois últimos quadrimestres do mandato, configurariam o tipo penal inscrito no artigo 359-C do Código Penal, alterado pela Lei $\mathrm{n}^{\mathrm{O}} 10.028 / 00$, que assim dispóe:

359-C - Ordenar ou autorizar a assunção de obrigação, nos dois últimos quadrimestres do último ano de mandato ou legislatura, cuja despesa não possa ser paga no mesmo exercício financeiro ou, caso reste parcela a ser paga no exercício seguinte, que não tenha contrapartida suficiente de disponibilidade de caixa.

Pena- reclusão, de 1 (um) a 4 (quatro) anos.

Como inscrever toda esta despesa já processada e não paga em Restos a Pagar, sem configurar-se o tipo penal, ante a inexistência de uma regra de transição?

Instado a manifestar-se o Tribunal de Contas do Estado do Paraná, através da Resolução $\mathrm{n}^{\circ}$ 1.106-TC, publicado em sua Revista de $\mathrm{n}^{\circ} 137$, sugere uma solução que compatibiliza aspectos materiais como legais

A \& C R. de Dir. Administrativo e Constitucional, Belo Horizonte, ano 4, n. 17, p. 139-170, jul./set. 2004 
nesta situação.

Em 04.05.2000, data da entrada em vigor da Lei Fiscal, deveria o Prefeito realizar um diagnóstico de suas dívidas até aquele momento. Ao final de seu mandato, comparar o valor obtido ao déficit em 31.12.2000 com este último devendo ser necessariamente ser menor ou igual ao apurado em maio.

Por ocasião da verificação "in loco" em cada Município, a situação seria analisada com um exame qualitativo nas despesas nos últimos oito meses de 2000.

Esta análise permitiria verificar a essencialidade das despesas em atividades administrativas ou não. Este caráter seria verificado caso a caso e permitiria não paralisar a Administração durante tanto tempo, que traria prejuízos irreparáveis à comunidade.

Por outro lado, o Prefeito ao atender esta orientação colocar-se-ia diante de uma das excludentes de antijuridicidade penal, ou seja, o estrito cumprimento do dever legal ante o caráter essencial das atividades.

O múnus público exercido pelo Prefeito de zelar pelo interesse público, consubstanciado nesta situação pela manutenção da prestação de serviços, verificaria que sua conduta não implicaria na tipificação da conduta estabelecida pelo artigo 359-C do Código Penal tendo, ainda, a prova préconstituída e devidamente atestada pelo Tribunal de Contas.

Tal situação não se cinge apenas àquele momento do final da gestão em 2000, mas também observaremos sua ocorrência em vários Municípios ao final da gestão atual em de 2004, pois teremos dívidas de exercícios anteriores e a necessidade de atender-se ao princípio da continuidade da prestação dos serviços públicos, ocasião em que os Prefeitos devem realizar procedimento semelhante ao sugerido pelo Tribunal de Contas do Paraná, precavendo-se de eventuais dissabores, quando já fora do exercício do cargo, com relação a despesas de anos anteriores a sua gestão.

Cabe ressaltar que a orientação da entidade de Municípios Paulistas acabou não encontrando amparo no Tribunal de Contas, que se manifestou reiteradamente contrário à adoção desta medida, com se observa nas decisões a seguir:

\section{Restos a Pagar cancelados e sem provisão de recursos}

TC 2594/026/00, $2^{\text {a }}$ Câmara, sessão de 09.04.02, Contas Municipais

Contas com várias falhas, entre elas, o cancelamento de Restos a Pagar de exercícios anteriores em dezembro de 2000, sem justificativas. Tal fato prejudica

A \& C R. de Dir. Administrativo e Constitucional, Belo Horizonte, ano 4, n. 17, p. 139-170, jul./set. 2004 
aqueles que de boa fé prestaram serviços ou forneceram bens ao Poder Público, retirando ainda do passivo, indevidamente, despesas realizadas, que deveriam onerar o orçamento de 2000. Contribui, ainda, para a emissão de parecer desfavorável, a inscrição na conta Restos a Pagar de despesas de caráter não continuado realizadas nos dois últimos quadrimestres do último ano de mandato do prefeito. Comunique-se ao Ministério Público a eventual infração à Lei de Crimes Fiscais, enviando cópia dos autos àquela instituição. ${ }^{4}$

\section{Restos a Pagar sem suporte financeiro é irregularidade grave}

TC 2270/026/00, 2ª Câmara, sessão de 21.05.02, Contas Municipais

O Chefe do Executivo não logrou afastar irregularidades graves, como a falta de suporte financeiro para os Restos a Pagar, parte destes referentes a obrigações assumidas na vigência da Lei de Responsabilidade Fiscal. Ainda se não bastasse, observou-se o cancelamento de Restos a Pagar de exercícios anteriores, medida que distorce a verdade fiscal das contas em questão. Voto, assim, pela emissão de parecer desfavorável à aprovação das mesmas. ${ }^{5}$

Impõe observar que tais dispositivos tanto da Lei de Responsabilidade Fiscal como da Lei $\mathrm{n}^{\mathrm{o}} 10.028 / 00$, extremamente salutares às finanças do Município, não têm o condão de emperrar a Administração tornando-a ao imobilismo absoluto, com a interrupção das atividades habituais e que tenham caráter imprescindível à comunidade.

Neste sentido, é de observar-se o resumo da decisão proferida pelo Tribunal de Contas do Estado de São Paulo, que assim estabelece:

\section{Nem todas as despesas em fim de mandato são vedadas pela LRF}

TC 2258/026/00, $2^{\text {a }}$ Câmara, sessão de 19.03.02, Contas Municipais.

A Lei Complementar 101/00, proíbe, apenas, nos dois quadrimestres finais do mandato eletivo, que seja assumida obrigação de despesa que não possa ser cumprida integralmente dentro do exercício ou que tenha parcelas a serem pagas no exercício seguinte sem que haja suficiente disponibilidade de caixa. A vedação alcança somente as obrigações novas, donde não há de se condenar a ocorrência de dispêndios continuados e obrigatórios para a manutenção das atividades públicas, mesmo quando empenhados nos dois terços finais do último ano do mandato eletivo, sob pena de se prejudicar a continuidade dos serviços públicos. De se considerar, ainda, a existência de obrigações a serem empenhadas no final do exercício, cuja liquidação se processará no subseqüente, como, por exemplo, os encargos sociais sobre a folha de pagamentos de dezembro e relativos ao $13^{\circ}$ salário. Infração ao artigo $42^{\circ}$ da LRF não caracterizada. Pela emissão de parecer favorável. ${ }^{6}$ (g.m.)

Este julgado de grande relevância no sentido de constituir-se em

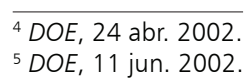

A \& C R. de Dir. Administrativo e Constitucional, Belo Horizonte, ano 4, n. 17, p. 139-170, jul./set. 2004 
elemento norteador do gestor das coisas dos Municípios nos dois quadrimestres finais do mandato, deve ser observado com bastante atenção e cautela, sob pena de acabar ensejando uma série de dissabores tanto para a autoridade como para a própria sociedade.

Impõe verificar que para que uma decisão desta natureza seja proferida, dois princípios norteadores da Administração devem ser observados de forma bastante clara e acentuada, por ocasião da assunção da despesa.

Trata-se do princípio da motivação, que na verdade, singelamente implica na necessidade da declaração por parte da Administração Pública em declinar as razões de fato e de direito que levam àquela ação.

O julgado da Corte Paulista de Contas ressalta com bastante clareza, que constitui-se em infração ao artigo 42 da Lei de Responsabilidade Fiscal, despesas novas, não abrangendo aquelas de natureza obrigatória e continuada, necessárias para manutenção e assecuratórias da continuidade da prestação do serviço público.

Esta decisão também põe em relevo, o princípio da continuidade da prestação do serviço público, que por si só, não tem o condão de justificar novas despesas que não possam ser suportadas integralmente naquele exercício do período vedado. São aceitáveis aquelas decorrentes de obrigação permanente da Administração, como também aquelas recobertas pelo caráter de essencialidade para o cidadão e por esta condição, não possam ser interrompidas sob grave dano.

Neste sentido cabe observar que os serviços públicos não podem parar pois os anseios da coletividade não param, eis que os desejos dos administrados são contínuos.

A atividade da Administração Pública deve ser ininterrupta, não se admitindo paralisação de serviços como: segurança pública, distribuição da justiça, saúde, transporte, extinção de incêndio, funerários, entre outras. Tal imposição, no caso dos Municípios, acaba ensejando como conseqüência material, alguns aspectos relevantes como:

a) Artigo 37, VII da CF, que reconhece o direito de greve do servidor, cinge seu exercício, nos termos limites da lei que vier a regulamentá-lo e que ainda não foi editada.

b) Proibição àqueles que contratam com a Administração Pública utilizar-se da exceção do contrato não cumprido (prevista nos artigos 476 e 477 do Novo Código Civil), ou seja, que nos contratos nenhum dos contraentes, antes de cumprida sua obrigação, pode ${ }^{6} D O E, 4$ abrezobigir o implemento do outro).

A \& C R. de Dir. Administrativo e Constitucional, Belo Horizonte, ano 4, n. 17, p. 139-170, jul./set. 2004 
c) Administração pode utilizar instalações e bens daqueles que contrata para assegurar a continuidade dos serviços.

d) Permite ainda a encampação de serviço público delegado.

A atividade não precisa ser ininterrupta, intermitente, mas sim, apenas regular. Ex.: serviço de verificação de segurança de elevadores, que ocorre a cada seis meses, serviço eleitoral e bolsas de estudo. Ressalte-se que é irrelevante este intervalo desde que haja regularidade, para que possamos falar em continuidade.

Estes aspectos ressaltados adquirem contornos relevantes, a partir de verificação de decisões do Tribunal de Contas do Estado de São Paulo que, ante a inobservância destes, declaram a ilegalidade da conduta.

Declarada a ilegalidade da conduta, verifica-se a existência de infração ao artigo 42 da Lei Fiscal, e por conseguinte, configuração, em tese, do tipo penal estabelecido no artigo 359-C da Lei $n^{\circ} 10.028 / 00$, a lei que estabelece os crimes contra as finanças públicas.

\section{Restos a Pagar sem lastro financeiro é crime fiscal}

TC 2302/026/00, $1^{\text {a }}$ Câmara, sessão de 03.09.02, Contas Municipais

É irregularidade relevante a inscrição em Restos a Pagar, sem a correspondente provisão de recursos, de despesas assumidas nos dois quadrimestres finais do exercício, incluído o período compreendido entre 19.10 e 31.12.2000. Tal conduta desborda da vedação contida no artigo 42 da Lei Complementar 101/00, podendo caracterizar a infração tipificada na Lei de Crimes Fiscais. Somente esta falha, independentemente de outras de igual gravidade, como a insuficiente aplicação de recursos na manutenção e desenvolvimento do ensino como um todo (art.212 da CF.) e no ensino fundamental (art. 60 do ADCT), já determina a desaprovação das contas. ${ }^{7}$ (g.m.)

Restos a Pagar sem disponibilidade de caixa pode configurar infração penal TC. 2253/026/00, $1^{\text {a }}$ Câmara, sessão de 19.02.02, Contas Municipais

Os desacertos apontados pela Auditoria em vários itens do relatório, para os quais a Origem não demonstrou interesse em oferecer justificativas, levam à formação de juízo desfavorável à aprovação das contas em apreciação. Sem embargo, determino o encaminhamento de cópia dos autos ao douto Ministério Público da Comarca, para apuração de eventual responsabilidade criminal, nos termos da Lei 10.028/00, ante a constatação de infração ao artigo 42 da Lei de Responsabilidade Fiscal, que veda, nos dois últimos quadrimestres do mandato do Prefeito, inscrições em Restos a Pagar de valores superiores à disponibilidade financeira do município.

(Artigo 359-C da Lei 10.028/00, Lei de Crimes Fiscais: "Ordenar ou autorizar a assunção de obrigação nos dois últimos quadrimestres do último ano de mandato ou legislatura, cuja despesa não possa ser paga no mesmo exercício financeiro ou,

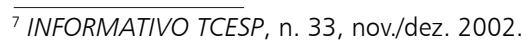

A \& C R. de Dir. Administrativo e Constitucional, Belo Horizonte, ano 4, n. 17, p. 139-170, jul./set. 2004 
caso reste parcela a ser paga no exercício seguinte, que não tenha contrapartida suficiente de disponibilidade de caixa. Pena: reclusão de um a quatro anos."

Aos mandatários municipais e aos ordenadores de despesas cabe observar que na orientação formulada pelas Cortes de Contas dos vários Estados brasileiros, um argumento bastante interessante deve ser salientado. Já foi apontado a partir da análise das próprias decisões, ou seja, o que significa a vedação instituída no artigo 42 da Lei de Responsabilidade Fiscal, ao coibir a contração de novas despesas sem o necessário provisionamento de recursos.

Já foi ressaltado que despesas decorrentes da necessidade de observância da continuidade do serviço público e as de natureza legal ou constitucional, poderiam vir a ser contraídas sem infringência ao dispositivo referenciado.

Neste sentido, em interessante parecer de José Nilo de Castro, encontra-se textualmente:

6 Inicialmente, chama-se a atenção para o significado do verbo contrair que constitui o núcleo do comando proibitivo quando diz a lei:

6.1 A significação contextual do verbo em questão está a representar o ato de vontade do administrador no sentido de contratar alguma despesa ou fazer algum ajuste. Em outras palavras, a proibição reside no excesso discricionário.

6.2 De sorte que, considerando a compreensão clássica e sempre válida na interpretação das leis, de que o legislador não usa palavras inúteis, conclui-se que as despesas, para cujo concurso o Administrador não colaborou com ato de vontade, com discricionariedade, não estão englobadas na vedação contida no artigo 42 da Lei Fiscal.

6.4 Desse modo, as despesas com folha de pagamento, dentre outras, por decorrem de imposição de ordem constitucional, estão à margem da proibição, prevista no artigo 42 da Lei Complementar $n^{\circ} 101 / 00$, fazendo com que, se inscrita em Restos a Pagar, não venha, referida inscrição, representar irregularidade, ou risco, ou risco ao Administrador que a tenha determinado. ${ }^{9}$

Tal conclusão acaba por oferecer importante instrumento àqueles que estão à frente das coisas de Municípios, tanto na esfera de verificação da regularidade de sua gestão pelos Tribunais de Contas, como também no sentido de eventual apuração de infração penal, agora na esfera do 
Judiciário.

Torna-se importante ressaltar que o argumento de forma isolada não tem qualquer relevância, devendo ser amplamente demonstrada a situação, mediante a elaboração de planilhas demonstrativas, que consigam apresentar, de forma consistente e irretorquível, que as despesas transferidas para o exercício subseqüente, sem a necessária reserva de recursos, são decorrentes, basicamente, de expresso mandamento legal ou constitucional, e demonstrando, com clareza, a inexistência de toda e qualquer discricionariedade na despesa assumida.

\section{Despesas assumidas nos últimos dois quadrimestres de mandato de prefeitos sem infringir o artigo $42 \mathrm{da}$ Lei de Responsabilidade Fiscal}

Até este momento restou evidenciada a preocupação do legislador em vedar permanente rolagem de dívidas nos entes públicos, notadamente daquelas de uma Administração para outra.

Esta preocupação materializa-se no que dispõe o artigo 42, ao impor que as despesas realizadas nos dois quadrimestres do final de mandato dos Prefeitos, se pagas no exercício subsequente, deverão ter o necessário suporte financeiro. Foi o legislador além, ao estabelecer que a violação desta regra configura tipo penal punido com detenção de seis meses a dois anos.

A abordagem já realizada no item anterior, apresenta alguns procedimentos que podem ser acolhidos e adotados pelos Prefeitos, ao ingressarem no período de alerta, ou seja, de final de mandato.

Um aspecto ainda não ressaltado deve ser abordado visando permitir que o Administrador consiga enfrentar este período e ainda assegurar com ações efetivas, o interesse de suas comunidades.

Trata-se daquelas despesas decorrentes de contratos celebrados pela Administração e que ultrapassam de um exercício para outro. Como deverá a Administração proceder no que se refere a provisionamento de recursos financeiros? Há a necessidade de reservar-se recursos do último ano de gestão do Prefeito, transferindo para o exercício subseqüente, mesmo que ainda não tenha sido implementado o objeto do contrato?

O Tribunal de Contas da Paraíba ao ser consultado pela Prefeitura de João Pessoa, assim manifestou-se:

\section{PARECER PN TC 02/2001}

\footnotetext{
${ }^{9}$ Boletim de Direito Municipal, n. 7, p. 200.
}

A \& C R. de Dir. Administrativo e Constitucional, Belo Horizonte, ano 4, n. 17, p. 139-170, jul./set. 2004 
Ementa: Consulta formulada pela Secretária Adjunta do Planejamento do Município de João Pessoa, sobre temas relacionados com a Lei de Responsabilidade Fiscal.

VISTOS, RELATADOS e DISCUTIDOS os presentes autos do Processo TC $n^{\circ}$ 9008/00, referente à consulta formulada pela Secretária Adjunta do Planejamento do Município de João Pessoa, Sra. Rúbria Beniz Gouveia Beltrão, e

CONSIDERANDO que a consulta tanto foi formulada por autoridade competente como seu objeto se insere no âmbito da competência deste Tribunal;

CONSIDERANDO que o parecer do Representante do Ministério Público perante este Tribunal, Dr. André Carlo Torres Pontes, enfoca com absoluta precisão os aspectos que envolvem a matéria de que trata a consulta, cuja conclusão merece, por isso mesmo, ser integralmente acolhida;

CONSIDERANDO o voto do Relator e o mais que dos autos consta,

O TRIBUNAL DE CONTAS DO ESTADO DA PARAÍBA, à unanimidade, em sessão plenária realizada nesta data, decide conhecer da consulta e, no mérito, responder nos termos do pronunciamento do representante do Ministério Público perante este Tribunal, cujo teor passa a fazer parte integrante deste Parecer.

Presente ao julgamento o Dr. Procurador Geral.

TCE - PLENÁRIO MINISTRO JOÃO AGRIPINO, de janeiro de 2001.

A questão remete à análise do art. 42, da LRF, vazado nos seguintes termos:

“Art. 42. É vedado ao titular de Poder ou órgão referido no art. 20, nos últimos dois quadrimestres do seu mandato, contrair obrigação de despesa que não possa ser cumprida integralmente dentro dele, ou que tenha parcelas a serem pagas no exercício seguinte sem que haja suficiente disponibilidade de caixa para este efeito.

Parágrafo único. Na determinação da disponibilidade de caixa serão considerados os encargos e despesas compromissadas a pagar até o final do exercício."

Recentemente, este Egrégio Tribunal, ao responder consulta advinda, também, do Município de João Pessoa, versando sobre quitação de obrigações de despesas em decorrência de contratos que ultrapassavam o exercício financeiro final de mandato, ofertou, a partir dos pronunciamentos dos ilustres Diretor Executivo Geral Luzemar da Costa Martins e Procuradora Isabella Barbora Marinho Falcão, a seguinte orientação:

“1) Se a vigência do contrato respeitar o exercício financeiro, deve-se entender que o titular do órgão terá de quitar as contraprestações realizadas até 31.12. Caso tenha de lançar mão dos Restos a Pagar, deverá possuir disponibilidade de caixa;

2) Se o contrato é firmado com prazo superior ao exercício, o titular do órgão deverá disponibilizar, ao fim do exercício, os recursos que cobrirão os serviços até então executados pelo contratado.”

Em sua manifestação, asseverou a d. Procuradora:

"Ao referir-se a "obrigação de despesa", o art. 42, em seu parágrafo único, 
considera como tal as despesas compromissadas a pagar até o final do exercício, ou seja, aquelas que ultrapassaram ou irão ultrapassar a fase de liquidação do empenho até o final do exercício.

Assim, só são considerados, para fins de disponibilidade de caixa, os Restos a Pagar processados até o final do exercício, o restante das obrigações assumidas (despesas cujo empenho não foi liquidado porque a obrigação não foi implementada) ficaria para ser pago por conta do orçamento dos exercícios seguintes, à medida em que se desse a prestação de seu objeto."

Desta forma, deverão ser integralmente pagas, ou consideradas para fins de disponibilidade de caixa, as obrigações constituídas nos últimos oito meses de mandato, que serão aquelas relativas à conclusão das fases ou etapas de execução do objeto contratado ou adimplemento de cada parcela, de acordo com o prévio e minucioso planejamento realizado. As fases ou parcelas restantes da execução do objeto contratado serão processadas no exercício em que se constituírem as respectivas obrigaçóes de despesa.

Ante o exposto, opino, em preliminar, pelo conhecimento da consulta e, no mérito, pela oferta de resposta ao consulente nos termos deste parecer e do pronunciamento da d. Auditoria. (g.m.)

Também o Tribunal de Contas do Estado de São Paulo instado a manifestar-se por representação formulada por interessado em licitação de prestação de serviço de coleta domiciliar de lixo veio a manifestar-se sobre esta situação, que será comum em todo final de mandato de Prefeitos.

Cabe ressaltar que a representação formulada pelo interessado deuse com base no artigo $113, \S 1^{\circ}$ da Lei ${ }^{\circ}$ 8.666/93, o Estatuto de Licitações, que textualmente estabelece: "qualquer licitante, contratado ou pessoa física ou jurídica, poderá representar ao Tribunal de Contas ou aos órgãos integrantes do sistema de controle interno contra irregularidades na aplicação desta Lei, para os fins do disposto neste artigo." (g. m.)

Observa-se que a representação formulada pelo interessado deu-se não por eventual infração à Lei de Licitações, e sim, à Lei de Responsabilidade Fiscal, aspecto salientado na decisão. Mesmo ante este aspecto, não se esquivou de apreciar a questão da contratação deste importante serviço público, no período indicado pelo artigo 42 da Lei Fiscal, assim assentando:

NÚMERO DO PROCESSO: TC- 24880/026/00

Matéria: Representação

Relator: Conselheiro Eduardo Bittencourt Carvalho

Objeto: edital de Concorrência 1/00 objetivando a Contratação de Serviços de Limpeza Pública e Manutenção Urbana

A peça formulada pelo sr. Mario Eliseo Botega procura impugnar o edital por infringêneia à Lei Gomplementar no 101 , de 04.05 .2000 , cujo artigo 42 veda A \& C R. de Dir. Administrativo e Constitucional, Belo Horizonte, ano 4, n. 17, p. 139-170, jul./set. 2004 
titulares de poder, nos últimos dois quadrimestres do seu mandato, contrair obrigação de despesa que não possa ser cumprida integralmente dentro dele.

Lembra o autor que, no exercício em andamento, teremos eleições para prefeito e que a administração de Caieiras não esta atentando para a regra advinda da Lei de Responsabilidade Fiscal, porquanto esteja por efetuar contratação ha três meses do final do mandato eletivo.

Quanto a representação formulada pelo sr. Mario Eliseo Botega, é de se ter em mente que o seu lastro não se encontra fincado em qualquer hipótese de irregularidade derivada da aplicação da lei de licitações, não se enquadrando na previsão do parágrafo $1^{\circ}$, do artigo 113 , do diploma em questão.

Sem perder de vista as diretrizes fundamentais advindas da Lei de Responsabilidade Fiscal (lei complementar número 101/2000), tenho que, em princípio, a regra do seu artigo 42 não se aplica a contratação de serviços essenciais, como o caso dos serviços de limpeza pública, justamente pelo ônus que a paralisação de serviços como os da espécie acabaria acarretando para toda a coletividade.

Assim, adstrito aos termos da inicial, considero prejudicada, por ora, a solicitação elaborada na peça processual.

Outrossim, determino o encaminhamento da matéria a auditoria da casa, para que sejam providenciadas as devidas anotações, de tal forma que subsidiem a futura e eventual contratação, inclusive no que tange as regras da lei de responsabilidade fiscal, cujos reflexos poderão, a juízo do relator, ser remetidos as próprias contas anuais da prefeitura. ${ }^{10}$ (g.m.)

A partir destas orientações de duas importantes Corte de Contas do país, é possível a celebração de contratos nos dois quadrimestres finais de mandato dos Prefeitos, cuja vigência ultrapasse para o novo exercício financeiro e consequentemente nova administração, sem a necessidade de disponibilidade de caixa com relação a toda a vigência do instrumento. Tal situação é possível desde que o Administrador precavenha-se com algumas cautelas imprescindíveis no sentido de encontrar amparo no ordenamento jurídico ao promover tais contratações:

a) despesa originada no contrato a ser celebrado, de vê encontrarse em consonância com as chamadas leis orçamentárias (PPA, LDO e LOA), nos termos dos artigos 15, 16 e 17 da LRF;

b) na hipótese de celebração do contrato, ainda no exercício de final de mandato do Prefeito, e em havendo execução parcial de seu objeto, deverá ter seu pagamento ainda neste exercício. Agora na hipótese de não ocorrer o pagamento neste exercício, deverá haver a inscrição em Restos a Pagar, com a conseqüente cobertura de ${ }^{10} D O E, 7$ set. 2600 rsos em caixa para o devido pagamento, sem contudo, onerar 
o Orçamento do novo exercício;

c) a natureza de essencialidade da atividade para o interesse público desde que devidamente motivada e atenda ao princípio da continuidade da prestação do serviço público como decorrência da indisponibilidade do interesse público pelo Administrador.

\section{Bibliografia}

ATAliBA, Geraldo. Apontamentos de Ciência das Finanças, Direito Financeiro e Tributário. São Paulo: Revista dos Tribunais, 1969.

BALEEIRO, Aliomar. Uma Introdução à Ciência das Finanças. 15. ed. Rio de Janeiro: Forense, 1998.

BARROS, Luiz Celso. Ciência das Finanças - Direito Financeiro. 4. ed. São Paulo: Edipro, 1991.

BASTOS Celso Ribeiro. Curso de Direito Administrativo. 3. ed. São Paulo: Saraiva, 1999.

BOBBIO, Norberto. Estado, Governo, Sociedade - Para uma Teoria Geral da Política. São Paulo: Paz e Terra, 1987.

BRITO, Edvaldo. A Constituição Brasileira de 1988 - Interpretações. Rio de Janeiro: Forense Universitária.

BRUNO, Reinaldo Moreira. Lei de Responsabilidade Fiscal E̊ Orçamento Publico Municipal. Curitiba: Juruá 2003.

CARRAZA, Roque Antonio. Curso de Direito Tributário. 6. ed. São Paulo: Malheiros, 1994.

CASTRO, José Nilo de. Direito Municipal. Belo Horizonte: Del Rey.

CASTRO, Tupinambá Miguel. Da Tributação e do Orçamento Público. Rio de Janeiro: Aide, 1989.

CHALITA, Gabriel. Ética dos Governantes e dos Governados. São Paulo: Max Limonad, 1999.

CHALITA, Gabriel. O Poder. 2. ed. São Paulo: Saraiva, 1999.

CIRNE LIMA, Ruy. Princípios de Direito Administrativo. São Paulo: Revista dos Tribunais, 1987.

CITADINI, Antonio Roque. Comentários sobre a Lei de Licitações Públicas. São Paulo: Max Limonad, 1996.

COELHO, Fábio Ulhoa. Direito e Poder. São Paulo: Saraiva, 1992.

CRUZ, Flávio da. Lei de Responsabilidade Fiscal Comentada. São Paulo: Atlas, 2000.

DALARI, Dalmo de Abreu. Elementos de Teoria Gerais do Estado. 20. ed. São Paulo: Saraiva, 1998.

DI PIETRO, Maria Sylvia Zanella. Direito Administrativo. 11. ed. São Paulo: Atlas, 1999.

DI PIETRO, Maria Sylvia Zanella. Discricionariedade Administrativa na Constituição de 1988. São Paulo: Atlas, 1991

FERRAZ JR., Tércio Sampaio. Introdução ao Estudo do Direito. São Paulo: Atlas, 1988.

FIGUEIREDO, Lúcia Valte. Gurso de Direito Administrativo. São Paulo: Matheiros, 1994.
A \& C R. de Dir. Administrativo e Constitucional, Belo Horizonte, ano 4, n. 17, p. 139-170, jul./set. 2004 
FIGUEIREDO, Marcelo. Probidade Administrativa. São Paulo: Malheiros, 1995.

FRANCO SOBRINHO, Manoel de Oliveira. Ato Administrativo. São Paulo: Saraiva,1980.

GASPARINI, Diógenes. Direito Administrativo. 5. ed. São Paulo: Saraiva, 2000.

GIACOMONI, James. Orçamento Público. 9. ed. São Paulo: Atlas, 2000.

JARDIM, Eduardo Marcial Ferreira. Manual de Direito Financeiro e Tributário. 3. ed. São Paulo: Saraiva.

MARTINS JR., Wallace Paiva. Probidade Administrativa. São Paulo: Saraiva, 2001.

MACHADO JR., J. Teixeira. A Lei $n^{\circ} 4320$ Comentada. 30. ed. Rio de Janeiro: Ibam, 2000/2001.

MEDAUAR, Odete. Controle da Administração Pública. São Paulo: Revista dos Tribunais, 1993.

MEIRELLES Hely Lopes. Direito Administrativo Brasileiro. 25. ed. São Paulo: Malheiros, 2000.

MEIRELLES Hely Lopes. Direito Municipal Brasileiro. 3. ed. São Paulo: Revista dos Tribunais.

MELlO, Celso Antonio Bandeira de. Curso de Direito Administrativo. 11. ed. São Paulo: Malheiros, 1999.

MORAES, Alexandre de. Direito Constitucional. 8. ed. São Paulo: Atlas, 2000.

MOREIRA NETO Diogo de Figueiredo. Curso de Direito Administrativo. Rio de Janeiro: Forense, 1996.

MOTTA, Carlos Pinto Coelho; SANTANA, Jair Eduardo; FERNANDES, Jorge Ulisses Jacoby; ALVES, Léo da Silva et al. Responsabilidade Fiscal. Belo Horizonte: Del Rey, 2000.

NUNES, Luiz Antonio. A Lei, o Poder e os Regimes Democráticos. São Paulo: Revista dos Tribunais, 1991.

OLIVEIRA, Austen da Silva. O Município e a Lei de Responsabilidade Fiscal. São Paulo: Conam, 2000 .

OLIVEIRA, Régis Fernandes de. Ato Administrativo. São Paulo: Revista dos Tribunais, 1978.

PAZZAGLINI FILHO, Marino et al. Improbidade Administrativa - Aspectos Jurídicos da Defesa do Patrimônio Público. 4. ed. São Paulo: Atlas, 1999.

PROCESSO LEGISLATIVO DO CONGRESSO NACIONAL. Da Mensagem $n^{0}$ 483/99. Projeto de Lei Complementar no 18-A de 1999.

REVISTA DE DIREITO ADMINISTRATIVO. Fundação Getúlio Vargas, Renovar, abr.jun. 2000, v. 220

ROCHA, Cármem Lucia Antunes. Princípios Constitucionais da Administração Pública. Belo Horizonte: Del Rey, 1994.

SILVA, José Afonso da. Aplicabilidade das Normas Constitucionais. 3. ed. São Paulo: Malheiros, 1999.

SUNDFELD, Carlos Ari. Fundamentos de Direito Público. 3. ed. São Paulo: Malheiros, 1997.

TÁCITO, Caio. A Inexistência dos Motivos nos Atos Administrativos. RDA, 36/78.

TEMER, Michel. Elementos de Direito Constitucional. 12. ed. São Paulo: Malheiros, 1996.

A \& C R. de Dir. Administrativo e Constitucional, Belo Horizonte, ano 4, n. 17, p. 139-170, jul./set. 2004 
TOLOSA FILHO, Benedito. Comentários à Nova Lei de Responsabilidade Fiscal. Rio de Janeiro: Temas \& Idéias, 2000.

TORRES, Ricardo Lobo. Curso de Direito Financeiro e Tributário. 2. ed. Rio de Janeiro: Renovar, 1993.

TORRES, Ricardo Lobo. Orçamento na Constituição. Rio de Janeiro: Renovar, 1995. 